\title{
Ability of Selenium Absorption by Mycelia of Pleurotus eryngii (DC.:Fr.) Quél., Depending on Selenium Source in Medium
}

\section{Mirjana Stajic, ${ }^{1}$ Ilija Brčeski, ${ }^{2}$ Solomon P. Wasser, ${ }^{3}$ Eviatar Nevo, ${ }^{3}$ Jelena Vukojevic, ${ }^{1}$ ES Sonja Duletić-Laušević ${ }^{1}$}

${ }^{1}$ Institute of Botany, Faculty of Biology, University of Belgrade, Takovska 43, 11000 Belgrade, Serbia and Montenegro, email: stajicm@bfbot.bg.ac.yu; ${ }^{2}$ Faculty of Chemistry, University of Belgrade, Studentski trg 3, 11000 Belgrade, Serbia and Montenegro; ${ }^{3}$ Institute of Evolution, University of Haifa, Mount Carmel, Haifa 31905, Israel

Pleurotus eryngii is an important edible and medicinal species. Selenium (Se) is a trace element, which at nutritional levels has numerous anticarcinogenic or preventive effects against carcinogen-induced breast, colon, liver, and skin cancer in animals, but at higher levels is known to be toxic.

The aim of this investigation was to study how three different Se sources added to the synthetic medium in specific concentrations influenced the ability of the mycelia to absorb this microelement.

Eight investigated strains of $P$. eryngii var. eryngii (code numbers 193;201;356;507; 616; 711; 716; 728) and one P. eryngii var. tingitanus (code number 555) were taken from the Culture Collection of the Institute of Evolution, University of Haifa, Israel (HAI). Se was used in forms of sodium selenite $\left(\mathrm{Na}_{2} \mathrm{SeO}_{3}\right)$, sodium selenate $\left(\mathrm{Na}_{2} \mathrm{SeO}_{4}\right)$, and selenium dioxide $\left(\mathrm{SeO}_{2}\right)$ in the following concentrations: $0.3 \mathrm{mg} / \mathrm{L}$, $0.7 \mathrm{mg} / \mathrm{L}, 1 \mathrm{mg} / \mathrm{L}$, and $1.3 \mathrm{mg} / \mathrm{L}$. Se concentration in mycelia was measured by graphite furnace Atomic Absorption Spectrometer (VARIAN, Australia).

$\mathrm{Na}_{2} \mathrm{SeO}_{3}$ was a good Se source for the absorption by mycelia and for the incorporation in Se compounds in the cell in all investigated strains. The increase of Se concentration in the medium led to increase of its content in mycelia also, except in strain HAI 201.
In investigated strains of P. eryngii var. eryngii, Se concentration in mycelia increased with its addition to the medium, when Se was added in the form of $\mathrm{Na}_{2} \mathrm{SeO}_{4}$, except in HAI 201 and 507, where Se content in mycelia decreased compared to the control in Se concentration of $0.3 \mathrm{mg} / \mathrm{L}$, whereas in the presence of higher Se concentrations it increased. Strain HAI 711 proved to be the best Se absorber $(725 \mu \mathrm{g} / \mathrm{g}$ of dry weight at $1 \mathrm{mg} / \mathrm{L}$, and $575 \mu \mathrm{g} / \mathrm{g}$ of dry weight at $1.3 \mathrm{mg} / \mathrm{L}$ of Se concentration in the medium). In P. eryngii var. tingitanus, not only was decrease of Se concentration in mycelia noted compared to the control, but also its total absence, when Se was present in medium in concentration of $0.7 \mathrm{mg} / \mathrm{L}$.

$\mathrm{SeO}_{2}$ as well as $\mathrm{Na}_{2} \mathrm{SeO}_{3}$ were shown as good $\mathrm{Se}$ sources for its absorption and retention by mycelia of investigated strains. They easily absorbed Se from medium where it was presented in concentration of $1.3 \mathrm{mg} / \mathrm{L}$, except strain HAI 201 where the highest concentration of absorbed Se was in concentration of $0.7 \mathrm{mg} / \mathrm{L}$ in the medium.

Among investigated $\mathrm{Se}$ sources, $\mathrm{Na}_{2} \mathrm{SeO}_{3}$ appeared to be the most favorable, while $\mathrm{Na}_{2} \mathrm{SeO}_{4}$ was the least favorable source for Se absorption by mycelium in majority of studied strains. 